\title{
Allometric Equations to Predict Pinus palustris Biomass in the Southeastern United States
}

\author{
Aline Araújo Farias ${ }^{1}$ (D), Salvador A. Gezan ${ }^{2}$, Melissa Pisaroglo de Carvalho², \\ Antonio Carlos Ferraz Filho ${ }^{3}$ (D), Carlos Pedro Boechat Soares ${ }^{1}$ \\ ${ }^{1}$ Universidade Federal de Viçosa - UFV, Viçosa/MG, Brasil \\ ${ }^{2}$ University of Florida - UF, Gainesville/FL, United States of America \\ ${ }^{3}$ Universidade Federal do Piaui - UFPI, Bom Jesus/PI, Brasil
}

\begin{abstract}
Pinus palustris Mill. ecosystem is considered one of the most threatened of North America. In this context, studies on biomass quantification are fundamental for forest management plans. Thus, the objective of this study was to develop a set of allometric equations to predict total P. palustris stump-biomass. Biomass data were collected at different locations in the southeastern United States. A total of 119 allometric equations were fitted from the combination of explanatory variables: diameter at breast height $(\mathrm{DBH})$, height $(\mathrm{H})$, age $(\mathrm{I})$, basal area $(\mathrm{G})$, number of trees per hectare $(\mathrm{N})$, site index $(\mathrm{S})$ and quadratic diameter $(\mathrm{Dq})$. One of the models that presented the lowest residual standard error (Sy.x) and root mean square error (RMSE) was $\ln (\mathrm{W})=-0.9978+0.7082 .(\mathrm{H})+0.1009 \cdot \ln (\mathrm{H} \cdot \mathrm{DBH})-0.5310 .(\mathrm{N})-0.0003 \cdot \ln (\mathrm{Dq})$. Therefore, the insertion of dendrometric variables characteristic of forest stands has great efficacy in biomass prediction for trees from different sites.
\end{abstract}

Keywords: forest management, modeling, regression. 


\section{INTRODUCTION}

Longleaf pine (Pinus palustris Mill.) ecosystem is considered one of the most threatened in North America. The species previously occupied approximately 37 million hectares of coastal areas, from the state of Virginia to Texas through central Florida, in the southeastern United States. Current estimates suggest that only $2.2 \%$ of the original area remains in the country (Boring, 2007).

In Brazil, longleaf pine stands are established in lower proportion when compared to Pinus ellioti and Pinus taeda stands, mainly due to the growth stagnation in the shoots of trees in the early post-implantation years. However, provenance tests have shown that Pinus palustris has higher growth and lower stagnation of shoots, a period known as "grass stage", when planted in adequate locations such as Southern Brazil (Shimizu, 2008).

Measures of above-ground biomass are required to predict site productivity, and growth and yield of trees and stands (Gonzalez-Benecke et al., 2014b). Besides, forest biomass studies allow the quantification of nutrient cycling both for energy purposes and for the carbon credits market. These studies also provide support for the sustainable management of forest resources (Ratuchne et al., 2016).

According to Gonzalez-Benecke et al. (2014b), biomass models are usually based on the stem diameter with bark at breast height (DBH), or DBH and total tree height $(\mathrm{H})$ as independent variables. However, such models are restricted to specific stands and geographic locations. An alternative to improve the accuracy of allometric models is to add stand variables such as age, density, or productivity (Gonzalez-Benecke et al., 2014a).

Few models are found in the literature to predict height, diameter inside bark and volume for longleaf pine, and they are usually based on $\mathrm{DBH}$ and $\mathrm{H}$ as independent variables (Gonzalez-Benecke et al., 2014a). Only one model to predict height based on stand-level variables such as basal area, stand age, and stand density was found, resulting in a general model (Leduc \& Goelz, 2009).

The set of equations presented in this study provides conditions for a better understanding of forest biomass accumulation for one of the oldest species of the American territory, Pinus palustris (Boring, 2007).
To our knowledge, the set of general biomass models developed in this paper will be the second carried out for the species.

Thus, the objective was to develop a set of allometric equations to predict Pinus palustris above-stump biomass. Also, these models can be applied to longleaf pine trees from a wide variety of ages and stands.

\section{MATERIAL AND METHODS}

The database used in this study was provided by the University of Florida and collected at three different locations: Fort Benning, Camp Lejeune, and Polk County.

The Fort Benning military installation $\left(32.38^{\circ} \mathrm{N}\right.$, $84.88^{\circ} \mathrm{W}$ ) is located between the states of Alabama and Georgia. The land use was predominated by agriculture and grazing activities before the installation of the military base. Currently, approximately $84 \%$ of the area is reforested, and of these, $15 \%$ is composed of pure longleaf pine plantations. The terrain is characterized as predominantly rolling, with elevations between 58 and 225 meters. The climate of the region is humid and mild. The mean annual precipitation measured between 1982 and 2011 in Columbus, Georgia, is 1180 millimeters, and the mean annual temperature for the same period is $18.7^{\circ} \mathrm{C}$ (Samuelson et al., 2014).

The Camp Lejeune marine corps base is located in Jacksonville, North Caroline, and the climate is humid subtropical. Camp Lejeune holds ancient longleaf pine lands and their remaining habitats to support legally protected forest species and endangered animals, such as the red-cockaded woodpecker. The Lejuene base conducts studies on alternative soil preparation practices in humid sites, in partnership with the United States Forest Service (USFS), for the establishment of longleaf pine stands (Brockway et al., 2005).

Polk County $\left(27^{\circ} 57^{\prime} \mathrm{N}, 81^{\circ} 42^{\prime} \mathrm{W}\right)$ is located in the central part of Florida. The prevailing climate in the region is humid subtropical, characterized by hot and humid summers and mild, relatively dry winters. The average annual temperature is around $22^{\circ} \mathrm{C}$, and the average monthly temperature varies from approximately $16^{\circ} \mathrm{C}$ in January and $28^{\circ} \mathrm{C}$ in August. However, from June to September, the temperature can be above $32{ }^{\circ} \mathrm{C}$ (Spechler \& Kroening, 2007). 
The dataset consisted of measures of 100 longleaf pine trees, obtained from three different sites (Fort Benning, Lejeune and Polk County) including ages ranging from 5 to 87 years. The dataset contained tree-level variables: $\mathrm{DBH}$ (diameter at 1.37 meters, $\mathrm{cm}$ ), $\mathrm{H}$ (total height, $\mathrm{m}$ ) and $\mathrm{W}$ (total above-stump biomass, $\mathrm{kg}$ ), and stand-level variables: A (stand age, years), N (number of trees per hectare, $\mathrm{ha}^{-1}$ ), BA (stand basal area, $\mathrm{m}^{2} \mathrm{ha}^{-1}$ ); $\mathrm{Dq}$ (quadratic mean diameter, $\mathrm{cm}$ ) and $\mathrm{S}$ (site index, dominant height at reference age of 50 years, $\mathrm{m}$ ). The main features of tree-level and stand-level variables are shown in Table 1.

The fitting of equations was performed by the ordinary least squares method (OLS) using the R software (R Core Team, 2013). Biomass models were created using independent variables $\mathrm{H}$ and $\mathrm{DBH}$, as well as their modified forms: H.DBH2 (product of $\mathrm{H}$ by squared $\mathrm{DBH}$ ), $\ln \mathrm{H}$ (natural logarithm of $\mathrm{H}$ ), lnDAP (natural logarithm of $\mathrm{DBH}$ ), and $\ln \mathrm{H} . \mathrm{DBH}$ (natural logarithm of $\mathrm{H}$ by $\mathrm{DBH}$ ).

The Pearson correlation coefficient $\left(r_{x y}\right)$ was used to measure the degree of association among variables added to models. Only variables that showed positive or negative correlation were added to models analyzed in this study. The maximum number of possible combinations was performed among previously mentioned variables, which resulted in 63 models containing tree-level variables.

For generic biomass models, the following stand-level variables were added to traditional models: age (I), basal area $(G)$, number of trees per hectare $(N)$, site index $(S)$, quadratic diameter $(\mathrm{Dq})$, as well as their modified forms: ratio between $\mathrm{DBH}$ and $\mathrm{Dq}(\mathrm{Dp})$, natural logarithm of age (LnI), basal area (LnG), number of trees per hectare $(\mathrm{LnN})$, site index $(\mathrm{LnS})$, quadratic diameter $(\mathrm{LnDq})$, ratio between $\mathrm{DBH}$ and $\mathrm{Dq}(\mathrm{LnDp})$, and inverse of age $\left(\mathrm{I}^{-1}\right)$. Since the combination of these variables would generate thousands of models for analysis, making it impossible to evaluate all of them, a correlation matrix was used to choose 56 models containing stand-level variables.

Models were analyzed by the adjusted determination coefficient $\left(\mathrm{R}^{2}\right)$ and residual standard error $\left(\mathrm{S}_{\mathrm{y} . \mathrm{x}}\right)$ to evaluate the goodness of fit for biomass prediction models. The variance inflation factor (VIF) was calculated to verify the presence of multicollinearity among independent variables. All models with VIF > 10 were eliminated, as proposed by O’Brien (2007).

The validation process was performed by the k-fold cross-validation technique, in which database was randomly divided into 10 blocks: 9 blocks were used to fit biomass models, and then the remaining block was used to predict biomass values. This procedure was repeated 50 times and generated prediction errors for each tree. The root mean square error (RMSE) was used to evaluate the accuracy of models.

\section{RESULTS AND DISCUSSION}

\subsection{Model fitting}

Only 12 models resulted in VIF $<10$ of the total of 63 models containing $\mathrm{H}$ and $\mathrm{DBH}$ as explanatory variables. These models are represented by Equations 1-12.

$$
\begin{aligned}
& L n W=\beta_{0}+\beta_{1}(H)+\beta_{2}(D B H)+\varepsilon_{i} \\
& L n W=\beta_{0}+\beta_{1}(H)+\beta_{2}\left(H . D B H^{2}\right)+\varepsilon_{i}
\end{aligned}
$$

\begin{tabular}{|c|c|c|c|c|c|}
\hline Attribute & Units & Mean & $\begin{array}{l}\text { Standard } \\
\text { deviation }\end{array}$ & Minimum & Maximum \\
\hline I & years & 28.4 & 24.2 & 5 & 87 \\
\hline $\mathrm{DBH}$ & $\mathrm{cm}$ & 16.0 & 13.7 & 0.81 & 54.3 \\
\hline $\mathrm{H}$ & $\mathrm{m}$ & 11.5 & 7.7 & 0.55 & 30.4 \\
\hline $\mathrm{N}$ & n.ha ${ }^{-1}$ & 924 & 589.6 & 50 & 2150 \\
\hline BA & $\mathrm{m}^{2} \mathrm{ha}^{-1}$ & 14.2 & 8.6 & 0.21 & 30.2 \\
\hline $\mathrm{Dq}$ & $\mathrm{cm}$ & 16.9 & 10.7 & 1.80 & 51.1 \\
\hline W & $\mathrm{kg}$ & 262.3 & 492.5 & 0.20 & 2149.9 \\
\hline SI & $\mathrm{m}$ & 21.27 & 4.08 & 13.74 & 33.86 \\
\hline
\end{tabular}

Table 1. Summary statistics of longleaf pine dataset.

I: stand age; DBH: diameter outside-bark at 1.37 meters; H: total tree height; N: number of trees per hectare; BA: stand basal area; Dq: quadratic mean diameter; W: total above-stump biomass; SI: site index, dominant height at reference age of 50 years. 


$$
\begin{aligned}
& L n W=\beta_{0}+\beta_{1}(H)+\beta_{2} \ln (H)+\varepsilon_{i} \\
& L n W=\beta_{0}+\beta_{1}(H)+\beta_{2} \ln (D B H)+\varepsilon_{i} \\
& L n W=\beta_{0}+\beta_{1}(H)+\beta_{2} \ln (H \cdot D B H)+\varepsilon_{i} \\
& L n W=\beta_{0}+\beta_{1}(D B H)+\beta_{2}\left(H \cdot D B H^{2}\right)+\varepsilon_{i} \\
& L n W=\beta_{0}+\beta_{1}(D B H)+\beta_{2} \ln (H)+\varepsilon_{i} \\
& \operatorname{Ln} W=\beta_{0}+\beta_{1}(D B H)+\beta_{2} \ln (D B H)+\varepsilon_{i} \\
& \operatorname{Ln} W=\beta_{0}+\beta_{1}(D B H)+\beta_{2} \ln (H \cdot D B H)+\varepsilon_{i} \\
& L n W=\beta_{0}+\beta_{I} \ln \left(H \cdot D B H^{2}\right)+\beta_{2} \ln (H)+\varepsilon_{i} \\
& L n W=\beta_{0}+\beta_{1} \ln \left(H \cdot D B H^{2}\right)+\beta_{2} \ln (D B H)+\varepsilon_{i} \\
& \operatorname{Ln} W=\beta_{0}+\beta_{1} \ln \left(H \cdot D B H^{2}\right)+\beta_{2} \ln (H . D B H)+\varepsilon_{i}
\end{aligned}
$$

Some of the models selected by the VIF restriction presented high residual standard error (Table 2) and, consequently, were discarded before the cross-validation process.

The $5^{\text {th }}$ and $9^{\text {th }}$ models presented the best fit according to analyzed precision measurements, and all parameter estimates were significantly different from

\begin{tabular}{|c|c|c|}
\hline Model & $S_{y x}$ & $\mathbf{R}^{2}$ Adjust. \\
\hline 1 & 0.7206 & 0.9155 \\
\hline 2 & 0.6908 & 0.9223 \\
\hline 3 & 0.5883 & 0.9437 \\
\hline 4 & 0.3834 & 0.9761 \\
\hline 5 & 0.3783 & 0.9767 \\
\hline 6 & 0.546 & 0.515 \\
\hline 7 & 0.4624 & 0.9652 \\
\hline 8 & 0.456 & 0.9661 \\
\hline 9 & 0.3641 & 0.9784 \\
\hline 10 & 0.6999 & 0.9203 \\
\hline 11 & 0.5266 & 0.9548 \\
\hline 12 & 0.4417 & 0.9682 \\
\hline
\end{tabular}
zero $(\mathrm{P}<0.001)$. The $5^{\text {th }}$ model presented $\mathrm{R}^{2}=97.67 \%$, which means that this model can explain $97.67 \%$ of the variation in longleaf pine biomass. Similarly, the $9^{\text {th }}$ model showed a high determination coefficient, indicating that $97.84 \%$ of the variation in biomass values are explained by explanatory variables $\mathrm{DBH}$ and

Table 2. Statistics for the 12 biomass models containing tree-level variables and VIF $<10$. Best models are highlighted in bold.

$\mathrm{S}_{\mathrm{y} . \mathrm{x}}=$ Standard error; $\mathrm{R}^{2}$ Adjust. = adjusted; determination coefficient; VIF = variance; inflation factor. ln (H.DBH). The residual standard error was similar for both models. When the models analyzed result in similar statistics, a less complex model should be selected. In this case, the $9^{\text {th }}$ model was chosen over the $5^{\text {th }}$ model due to its lower residual standard error.

Models containing stand-level variables as explanatory variables and VIF $<10$ are represented by Equations13-26. Models that presented high residual standard error were not used in the cross-validation process (Table 3 ).

$$
\begin{aligned}
& L n W=\beta_{0}+\beta_{1}(D B H)+\beta_{2} \ln (H \cdot D B H)+ \\
& \beta_{3}(G)+\beta_{4} \ln (N)+\beta_{5} \ln \left(D_{q}\right)+\varepsilon_{i} \\
& L n W=\beta_{0}+\beta_{1}(D B H)+\beta_{2} \ln (H \cdot D B H)+ \\
& \beta_{3}(G)+\beta_{4}(N)+\beta_{5} \ln \left(D_{q}\right)+\varepsilon_{i} \\
& L n W=\beta_{0}+\beta_{I}(H)+\beta_{2} \ln (H \cdot D B H)+ \\
& \beta_{3}(G)+\beta_{4}(N)+\beta_{5} \ln \left(D_{q}\right)+\varepsilon_{i} \\
& L n W=\beta_{0}+\beta_{I}(H)+\beta_{2} \ln (H \cdot D B H)+ \\
& \beta_{3}(N)+\beta_{4} \ln \left(D_{q}\right)+\varepsilon_{i} \\
& L n W=\beta_{0}+\beta_{1}(D B H)+\beta_{2} \ln (H \cdot D B H)+ \\
& \beta_{3}(N)+\beta_{4} \ln \left(D_{q}\right)+\varepsilon_{i} \\
& L n W=\beta_{0}+\beta_{I}(D B H)+\beta_{2} \ln (H \cdot D B H)+\beta_{3}(N)+\varepsilon_{i} \\
& L n W=\beta_{0}+\beta_{1}(D B H)+\beta_{2} \ln (H . D B H)+\beta_{3} \ln (G)+\varepsilon_{i}
\end{aligned}
$$

Table 3. Statistics for the 14 biomass models containing stand-level variables and VIF $<10$. Best models are highlighted in bold.

\begin{tabular}{|ccc|}
\hline Model & $\mathbf{S}_{\mathbf{y} \mathbf{x}}$ & $\mathbf{R}^{2}$ Adjust. \\
\hline 13 & 0.3058 & 0.9848 \\
\hline 14 & 0.3067 & 0.9847 \\
$\mathbf{1 5}$ & $\mathbf{0 . 2 8 9 8}$ & $\mathbf{0 . 9 8 6 3}$ \\
$\mathbf{1 6}$ & $\mathbf{0 . 2 9 4 8}$ & $\mathbf{0 . 9 8 5 9}$ \\
\hline 17 & 0.3201 & 0.9833 \\
\hline 18 & 0.3502 & 0.98 \\
\hline 19 & 0.3264 & 0.9827 \\
\hline 20 & 0.3363 & 0.9816 \\
\hline 21 & 0.3529 & 0.9797 \\
\hline 22 & 0.3084 & 0.9845 \\
\hline 24 & 0.3191 & 0.9834 \\
\hline 25 & 0.348 & 0.9803 \\
\hline 26 & 0.4009 & 0.9738 \\
\hline
\end{tabular}

$\mathrm{S}_{y . \mathrm{x}}=$ Standard error; $\mathrm{R}^{2}$ Adjust. = adjusted determination coefficient; VIF = variance inflation factor. 


$$
\begin{aligned}
& L n W=\beta_{0}+\beta_{1}(D B H)+\beta_{2} \ln (H \cdot D B H)+\beta_{3} \ln \left(D_{q}\right)+\varepsilon_{i} \\
& L n W=\beta_{0}+\beta_{1}(H)+\beta_{2} \ln (H \cdot D B H)+\beta_{3}(N)+\varepsilon_{i} \\
& L n W=\beta_{0}+\beta_{1}(H)+\beta_{2} \ln (H \cdot D B H)+\beta_{3} \ln (G)+\varepsilon_{i} \\
& L n W=\beta_{0}+\beta_{1}(H)+\beta_{2} \ln (H \cdot D B H)+\beta_{3} \ln \left(D_{q}\right)+\varepsilon_{i} \\
& L n W=\beta_{0}+\beta_{1}(H)+\beta_{2} \ln (H \cdot D B H)+\beta_{3}\left(D_{p}\right)+\varepsilon_{i} \\
& L n W=\beta_{0}+\beta_{1} \ln (H \cdot D B H)+\beta_{2}(N)+\beta_{3} \ln \left(D_{q}\right)+\varepsilon_{i} \\
& L n W=\beta_{0}+\beta_{1} \ln (H \cdot D B H)+\beta_{2} \ln \left(D_{q}\right)+\varepsilon_{i}
\end{aligned}
$$

The $15^{\text {th }}$ and $16^{\text {th }}$ models were selected after evaluation of precision measurements. The determination coefficient $\left(\mathrm{R}^{2}\right)$ for the $15^{\text {th }}$ and $16^{\text {th }}$ models were $98.63 \%$ and 98.59\% respectively, confirming the ability of models to explain the variation in biomass values. Residual standard errors for the selected models were similar. In this situation, the simplest model should be chosen over the more complex one.

\section{a) $5^{\text {th }}$ Model}

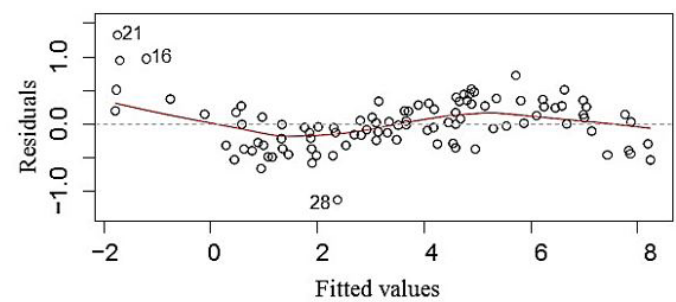

c) $15^{\text {th }}$ Model

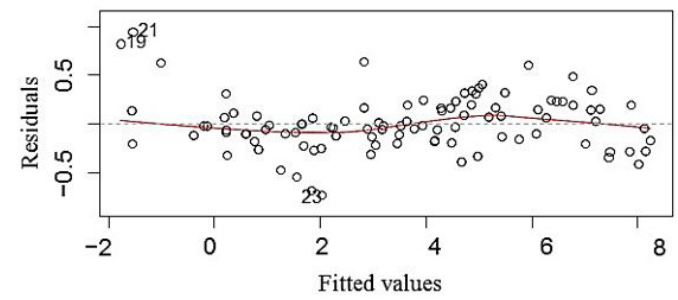

Residual scatterplots against predicted biomass values for the four selected models revealed residuals uniformly distributed around zero, despite the presence of some outliers for Longleaf pine trees with low biomass content (Figure 1).

The presence of outliers for lower biomass values can be explained by the higher frequency of adult trees in stands under study.

\subsection{Model validation}

Table 4 shows the RMSE values for the 4 selected models after cross-validation.

RMSE was lower when explanatory variables number of trees per hectare $(\mathrm{N})$, quadratic diameter $(\mathrm{Dq})$, and basal area $(\mathrm{G})$ were added to the $5^{\text {th }}$ biomass model.

Cross-validation confirmed the goodness of fit for the $15^{\text {th }}$ and $16^{\text {th }}$ models to predict biomass of Longleaf pine stands located in the southeastern United States, which reinforced the residual standard error results and scatterplots of models.

b) $9^{\text {th }}$ Model

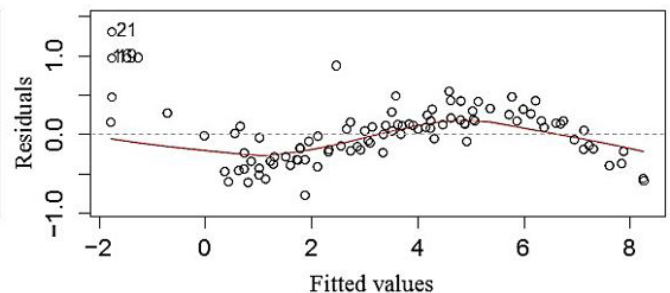

d) $16^{\text {th }}$ Model

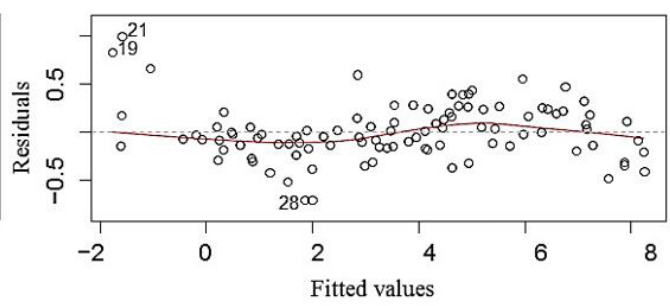

Figure 1. Residual scatterplots for the four selected models containing tree-level and stand-level variables.

Table 4. RMSE (Root Mean Square Error) comparison for the selected models after cross-validation.

\begin{tabular}{lc}
\multicolumn{1}{c}{ Models } & RMSE \\
$\mathbf{5}^{\text {th }}: \ln (W)=-1.8702+0.1114 .(H)+0.5818 \cdot \ln (H \cdot D B H)$ & 0.2838 \\
$\mathbf{9}^{\text {th }}: \ln (W)=-1.7709+0.0544 .(D B H)+0.6273 \cdot \ln (H \cdot D B H)$ & 0.2688 \\
\hline $\mathbf{1 5}^{\text {th }}: \ln (W)=-0.7785+0.7124 .(H)+0.0979 \cdot \ln (H \cdot D B H)-0.6353 \cdot(G)-0.0004 \cdot \ln (N)+0.0122 \cdot \ln (D q)$ & 0.2156 \\
$\mathbf{1 6}^{\text {th }}: \ln (W)=-0.9978+0.7082 .(H)+0.1009 \cdot \ln (H \cdot D B H)-0.531 .(N)-0.0003 \cdot \ln (D q)$ & 0.2090 \\
\hline
\end{tabular}


Accurate biomass equations are necessary to manage and monitor longleaf pine stands. The dataset used in this study covered different locations in the southeastern United States, and the models reported here can be applied to a wide variety of ages and stands. However, since there was no information on thinning practices for the stands, the models should be used in conditions of no strong thinning influence, as recommended by Gonzalez-Benecke et al. (2018).

Although the trees used in the modeling process have come from different locations, all stands presented similar features that allowed using multiple linear regression. Linearization of biomass models has been used in many studies (Repola, 2008; Litton \& Boone, 2008; Mugasha et al., 2013; Chave et al., 2014), mainly due to its simplicity (Ferraz Filho et al., 2018). Alternatively, other approaches can be used to increase the accuracy of growth predictions of forest stands such as Artificial Neural Networks (Binoti et al., 2013; Reis et al., 2016; Ferraz Filho et al., 2018), support vector machines (Cordeiro et al., 2015; Cosenza et al., 2015) and Quantile Regression (Araújo et al., 2016). However, these methods are computationally intensive and should be used with caution due to potential restrictions on extrapolations (Ferraz Filho et al., 2018).

\section{CONCLUSION}

The addition of stand-level variables to linear regression models has great efficacy to predict total Pinus palustris trees biomass from different sites. The explanatory variables quadratic diameter $(\mathrm{Dq})$, basal area $(\mathrm{G})$ and number of trees.ha-1 $(\mathrm{N})$ were crucial to capture stand variation and predict $P$. palustris biomass.

\section{ACKNOWLEDGEMENTS}

To CAPES Foundation for funding the scholarship to the first author, and to the University of Florida for providing monitoring data from different sites.

\section{SUBMISSION STATUS}

Received: 6 nov., 2018

Accepted: 4 dec., 2018

\section{CORRESPONDENCE TO}

\section{Aline Araújo Farias}

Departamento de Engenharia Florestal, Universidade Federal de Viçosa - UFV, Avenida Purdue, s/n, Edif. Reinaldo de Jesus Araújo, CEP 36570-900, Viçosa, MG, Brasil

e-mail: araujo.91@hotmail.com

\section{FINANCIAL SUPPORT}

Coordenação de Aperfeiçoamento de Pessoal de Nível Superior, (Grant/AwardNumber: 88888.041717/2013-00)

\section{REFERENCES}

Araújo CAA Jr, Soares CPB, Leite HG. Curvas de índices de local em povoamentos de eucalipto obtidas por regressão quantílica. Pesquisa Agropecuária Brasileira 2016; 51(6): 720-727. http://dx.doi.org/10.1590/S0100204X2016000600003.

Binoti MLMS, Binoti DHB, Leite HG. Aplicação de redes neurais artificiais para estimação da altura de povoamentos equiâneos de eucalipto. Revista Árvore 2013; 37(4): 639 645. http://dx.doi.org/10.1590/S0100-67622013000400007.

Boring LR. The longleaf pine ecosystem: ecology, silviculture, and restoration. Forest Science 2007; 53(5): 618.

Brockway DG, Outcalt KW, Tomczak DJ, Johnson EE. Restoration of longleaf pine ecosystems. Asheville: US Department of Agriculture, Forest Service; 2005. (General Technical Report Southern Research Station; no. SRS-83).

Chave J, Réjou-Méchain M, Búrquez A, Chidumayo E, Colgan MS, Delitti WB et al. Improved allometric models to estimate the aboveground biomass of tropical trees. Global Change Biology 2014; 20(10): 3177-3190. http:// dx.doi.org/10.1111/gcb.12629. PMid:24817483.

Cordeiro MA, Pereira NNJ, Binoti DHB, Binoti MLMS, Leite HG. Estimativa do volume de Acacia mangium utilizando técnicas de redes neurais artificiais e máquinas vetor de suporte. Pesquisa Florestal Brasileira 2015; 35(83): 255-261. http://dx.doi.org/10.4336/2015.pfb.35.83.596.

Cosenza DN, Leite HG, Marcatti GE, Binoti DHB, Alcântara AEM, Rode R. Classificação da capacidade produtiva de sítios florestais utilizando máquina de vetor de suporte e rede neural artificial. Scientia Forestalis 2015; 43(108): 955-963. http://dx.doi.org/10.18671/scifor.v43n108.19.

Ferraz Filho AC, Mola-Yudego B, Ribeiro A, Scolforo JRS, Loos RA, Scolforo HF. Height-diameter models for Eucalyptus sp. plantations in Brazil. Cerne 2018; 24(1): 9-17. http://dx.doi.org/10.1590/01047760201824012466. 
Gonzalez-Benecke CA, Gezan SA, Albaugh TJ, Allen HL, Burkhart HE, Fox TR et al. Local and general above-stump biomass functions for loblolly pine and slash pine trees. Forest Ecology and Management 2014b; 334: 254-276. http://dx.doi.org/10.1016/j.foreco.2014.09.002.

Gonzalez-Benecke CA, Gezan SA, Martin TA, Cropper WP Jr, Samuelson LJ, Leduc DJ. Individual tree diameter, height, and volume functions for longleaf pine. Forest Science 2014a; 60(1): 43-56. http://dx.doi.org/10.5849/ forsci.12-074.

Gonzalez-Benecke CA, Zhao D, Samuelson L, Martin T, Leduc D, Jack S. Local and general above-ground biomass functions for pinus palustris trees. Forests 2018; 9(6): 310. http://dx.doi.org/10.3390/f9060310.

Leduc D, Goelz J. A height-diameter curve for longleaf pine plantations in the Gulf Coastal Plain. Southern Journal of Applied Forestry 2009; 33(4): 164-170.

Litton CM, Boone KJ. Allometric models for predicting aboveground biomass in two widespread woody plants in Hawaii. Biotropica 2008; 40(3): 313-320. http://dx.doi. org/10.1111/j.1744-7429.2007.00383.x.

Mugasha WA, Eid T, Bollandsås OM, Malimbwi RE, Chamshama SAO, Zahabu E et al. Allometric models for prediction of above-and belowground biomass of trees in the miombo woodlands of Tanzania. Forest Ecology and Management 2013;310: 87-101. http://dx.doi.org/10.1016/j. foreco.2013.08.003

O' Brien RM. A caution regarding rules of thumb for variance inflation factors. Quality \& Quantity 2007; 41(5): 673-690. http://dx.doi.org/10.1007/s11135-006-9018-6.
Ratuchne LC, Koehler HS, Watzlawick LF, Sanquetta CR, Schamne PA. Estado da arte na quantificação de biomassa em raízes de formações florestais. Floresta e Ambiente 2016; 23(3): 450-462. http://dx.doi.org/10.1590/21798087.131515 .

R Core Team. R: a language and environment for statistical computing [online]. Vienna: The R Foundation; 2013 [cited 2018 Nov 6]. Available from: https://www.rproject.org/

Reis LP, Souza AL, Mazzei L, Reis PCM, Leite HG, Soares CPB et al. Prognosis on the diameter of individual trees on the eastern region of the amazon using artificial neural networks. Forest Ecology and Management 2016; 382: 161-167. http://dx.doi. org/10.1016/j.foreco.2016.10.022

Repola J. Biomass equations for birch in Finland. Silva Fennica 2008; 42(4): 605-624. http://dx.doi.org/10.14214/ sf.236.

Samuelson LJ, Stokes TA, Butnor JR, Johnsen KH, Gonzalez-Benecke CA, Anderson P et al. Ecosystem carbon stocks in Pinus palustris forests. Canadian Journal of Forest Research 2014; 44(5): 476-486. http://dx.doi. org/10.1139/cjfr-2013-0446.

Shimizu JY. Pinus na silvicultura brasileira. 1. ed. Colombo: Embrapa Florestas; 2008.

Spechler RM, Kroening SE. Hydrology of polk county, florida. 1st ed. Virginia: US Department of the Interior and US Geological Survey; 2007. http://dx.doi.org/10.3133/ sir20065320. 